\title{
ANTI-CASTE AESTHET(H)ICS IN CONTEMPORARY DALIT CINEMA: THE CASE OF ASURAN (2019)
}

\author{
Dolores Herrero \\ Universidad de Zaragoza*
}

\begin{abstract}
Mainstream Indian cinema has failed to denounce the social realities of casteism, depict diversity and vindicate inclusion. However, the advent of globalisation and new modern media and social platforms have contributed, not only to reinventing the very dynamics of cinema production and consumption, but also to developing new film genres that dare to question and counter hegemonic ideologies and aesthetics. This is the case of Dalit cinema, a movement of visual creative art made by Dalit film-makers with a view to embodying and dignifying Dalit subjectivities and inspiring socio-cultural criticism and resistance. The main aim of this paper will be to show how Dalit films like Vetrimaaran's Asuran strive to oppose the dominant aesthetics of stereotypical representation, thus denouncing casteist images and even developing innovative or subversive anti-caste aesthetics which prompt spectators to get involved in the ethical issues put forward and can in turn be labelled as anti-caste aesthet(h)ics.
\end{abstract}

Keywords: Dalit cinema, Mainstream Indian Cinema, Casteism, Anti-Caste Aesthetics, Asuran.

\section{ANTI-CASTA ESTÉTICA-ÉTICA EN EL CINE CONTEMPORÁNEO \\ DE LOS DALITS: EL CASO DE ASURAN (2019)}

\section{RESUMEN}

El cine indio establecido no ha sido capaz de denunciar la realidad social surgida como consecuencia del sistema de castas, ni de describir la diversidad o defender la inclusión. Sin embargo, la llegada de la globalización y de los nuevos medios de comunicación y plataformas sociales ha contribuido, no solo a reinventar las mismas dinámicas de producción y consumo cinematográficos, sino también a desarrollar nuevos géneros fílmicos que se atreven a cuestionar y contrarrestar la ideología y estética dominantes. Este es el caso del cine de los Dalits, un movimiento de arte creativo llevado a cabo por directores Dalits con el objetivo de representar y dignificar la subjectividad Dalit e inspirar y alentar la crítica socio-cultural y la resistencia. El principal objetivo de este artículo será mostrar cómo, a través del uso de técnicas audiovisuales y cinematográficas innovadoras, películas Dalits como Asuran, dirigida por Vetrimaaran, se afanan por oponerse a la representación estereotípica favorecida por la estética dominante, denunciando imágenes casteistas e implementar una innovadora, e incluso en ocasiones subversiva, estética anti-casta que incite a los espectadores a implicarse en las cuestiones éticas que plantea, y que por consiguiente permita calificarla como estética/ética anti-casta.

Palabras clave: cine Dalit, cine dominante indio, casteismo, estética anti-casta, Asuran.

DOI: https://doi.org/10.25145/j.recaesin.2021.83.03

Revista Canaria de Estudios Ingleses, 83; November 2021, pp. 37-49; ISSN: e-2530-8335 


\section{MAINSTREAM INDIAN CINEMA AND CASTE}

Indian cinema is, without doubt, the single largest medium of communication with the masses, and nearly twelve million Indians watch films in cinema theatres on a weekly basis (Butalia 1984: 108). The Indian film industry, popularly known as Bollywood (although, to be more precise, this term specifically refers to the globalised Bombay/Mumbai-based film industry), is the biggest in the world, as it produces approximately one thousand films every year. Since its very origins in 1930s, mainstream Indian cinema has tried to deal with the problems and multifarious aspects of Indian society, one of the most complex in the world as regards language, religion and culture. However, as many Indian critics have pointed out (see, among others, Edachira 2020, Yengde 2018 and Vidushi 2015), it is also undeniable that mainstream Indian cinema has been, on the whole, responsible for avoiding putting its finger on many thorny issues with a view to encouraging and sustaining the privileges of the dominant castes. ${ }^{1}$ To quote the words of Jiya Rani, a Dalit Indian journalist (in Pal 2019), "the mainstream media is not for the poor, not for the oppressed. It has carved its kingdom out of loyalty to the powers, to bureaucracy, to domination." Caste, a peculiar and deeply ingrained attribute of Indian society is, often, played down as a theme by assimilating it into other categories such as 'the poor,' 'the orphan' or 'the hard-working common Indian.' The same is true of secularism: in most Bollywood films, Muslims are systematically 'othered' while Hindu-Muslim relationships are toned down to enhance a positive image of India as a liberal and non-denominational country (see Chadha and Kavoori 2008).

It could therefore be argued that, as a national project, mainstream Indian cinema has failed, not only to denounce the social realities of casteism, but also to depict diversity as regards class, religion and gender dynamics, and thus to vindicate inclusion. Instead, Bollywood films illustrate and advocate the attitudes and beliefs upheld by the dominant upper castes, while often turning a blind eye to the gross violations of human rights and democratic rules that are perpetrated against the rest of the population in the country on a daily basis. Moreover, to rely on Yengde's term (2018: 3), the "Brahmanish" operations of India's Central Board of Film Certification (CBFC) have only contributed to further preserving this inequality. After Indian Independence, and mainly through the formation of the CBFC in 1951,

* The author gratefully acknowledges the support of the Spanish Ministry of Economy, Industry and Competitiveness (MINECO) and the European Regional Development Fund (DGI/ ERDF) (code FFI2017-84258-P); and the Government of Aragón and the FSE 2020-2022 programme (code H03_20R), for the writing of this essay.

${ }^{1}$ The Hindu caste system, also called varna caste order, divides society into four main castes or varnas (Brahmins, Kshatriyas, Vaishya and Shudras). Those who fall out of this system because of their inferior and polluting status are ostracised as outcastes (the untouchables, nowadays called Dalits) and considered outside the varna system. The upper castes, also known as twice-born and caste Hindus, are the three first groups mentioned: The Brahmins (religious and intellectual elite), the Kshatriyas (warriors and aristocrats), and the Vaishya (merchants, landlords and tradesmen). 
the Indian film industry strove to celebrate a conservative nationalism by forging the celebratory image of the country as a primarily agrarian society, loyal to the nation as embodied in its armed forces and deeply-rooted Hindu religious beliefs. This explains why mainstream Indian cinema became conspicuously escapist: by obliterating subaltern voices, these films managed to display a false utopian vision of Indian society that downplays caste inequalities, has very little to do with the reality of the great majority of the population, and by extension prevents Dalits from having their say in mainstream culture.

\section{THE REPRESENTATION OF DALITS IN BOLLYWOOD MOVIES}

Pre-Independence Indian films, such as Chandidas (1932), Devdas (1935), Malapialla (1938), Dharmatman (1935) and Achnut Kanya (1936), to mention but some, dealt with caste-related issues, mainly as a result of the anti-caste movement triggered off by intellectual B.R. Ambedkar. As Vidushi explains (2015: 126-132), although some post-Independence movies also tackle caste discrimination, their number is, by far, very limited and, with the exception of recent films such as Sanjiv Jaiswal's Shudra: The Rising (2012), which openly deals with the Dalit fight for their rights and self-respect by describing in great detail the deaths and ignominious deprivation suffered by a number of them to ultimately uphold rebellion, most of these films often offer a restricted and biased treatment of Dalit issues. To give an example, discrimination and violence against Dalit women in particular has been widely showcased, but mainly because the figure of the good suffering woman is a most commercial Bollywood trope. Bimal Roy's Sujata (1959), which tells the story of an orphaned Dalit baby girl who is adopted by a Brahmin couple and must consequently suffer the rejection of the community in which she lives, and Shyam Benegal's trilogy -Ankur (1974), Manthan (1976) and Nishant (1975)- which denounces how the powerful upper castes dominate and humiliate Dalits, all the more so if they happen to be women, could be two cases in point.

Honour killings as a result of inter-caste romantic love is another common subject of Bollywood films featuring Dalit characters, as can be seen in Rajkumar Santoshi's Lajja (2001) and Priyadarshan's Aakrosh (2010). Lajja brings to the fore the plight of all women in India, and Dalit ones in particular. The fact that the names of the four main female characters (Maithili, Janki, Vaidehi and Ramdulaari, this forth being a Dalit woman) are all versions of Sita, the ideal Hindu woman's name, makes it clear that, in spite of all differences, they are all on an equal footing. However, it is Ramdulaari, the Dalit woman, who is ultimately raped and killed by the landlords so as to prevent her son's marriage with an upper-caste woman. For its part, Aakrosh tells the story of a murder inquiry into the deaths of three medical students who are killed because one of them tried to elope with an upper-caste girl.

On the whole, although most of these films seem to try to generate sympathy for the Dalit cause, they mainly focus on exceptional individuals who accordingly deserve a better life, rather than openly questioning social exclusion and speaking 
in favour of substantial changes. A good example of this could be Shekhar Kapur's box-office success Bandit Queen (1994), which features the real life of Phoolan Devi, an extraordinarily brave and daring Dalit woman who was sexually abused repeatedly by the upper-caste landlords in her village. Finally, another popular trope in Bollywood films is that of the upper-caste man (again, an exceptional individual) who strives to improve the living conditions of his nearby downtrodden Dalits. Ashutosh Gowariker's Lagaan (2001) and Swades (2004) could very well serve as illustrations. Lagaan tells the story of a small village under the British rule where farmers, due to drought, cannot possibly give part of their crop in order to pay a tax called lagaan. The upper-caste protagonist will help them all-Hindu, Muslim, Sikh and a Dalit called Kachra, which literally means 'garbage' - to come together and make up the cricket team that will beat that of British soldiers who, having lost the bet, will be obliged to cancel the payment of taxes for the next three years. As regards Swades, it is about an upper-caste educated man working in the United States who returns to the Indian village where he was born. A convinced supporter of democracy, he tries to fight against casteism by sponsoring, among other things, the screening of a film for the entire community, Dalits included.

As to whether these films have actually contributed to changing people's minds as regards the myriad injustices perpetrated in India with a view to preserving the caste system and the old-time discriminatory beliefs that it enforces, the answer is still no. Actually, famous Indian actors and actresses often endorse good causes (women's rights, animals' rights and the like), but seldom denounce caste oppression. Generally speaking, Bollywood films have cultivated and promoted the myth of an open and diverse country, while systematically skewing and shunning the evidence of pervading reprehensible socio-political atrocities.

\section{THE EMERGENCE OF DALIT CINEMA AND ANTI-CASTE AESTHETICS: THE CASE OF ASURAN (2019)}

In order to denounce the injustice of misrepresentation (if any), an everincreasing number of Dalit voices have been raised in the fields of literature, social activism and, more importantly, cinema. ${ }^{2}$ It is clear that the enormous amount of

\footnotetext{
2 Some of the most well-known contemporary Dalit authors and activists are: Namdeo Dhasal (Marathi), Meena Kandasamy (English), Bama (Tamil), Urmila Pawar (Marathi and English), Baburao Bagul (Marathi), Jatin Bala (Bengali), Ajay Navaria (Hindi), Baby Kamble (Marathi), Imayam (Tamil), Manoranjan Byapari (Bengali), Raja Dhale (Marathi), Dev Kumar (Hindi), Devanur Mahadeva (Kannada), Siddalingaiah (Kannada), Goyu Shyamala (Telugu), P. Sivakami (Tamil), Omprakash Valmiki (Hindi), Debi Roy (Bengali) and Yashica Dutt (Hindi). As far as Dalit film directors are concerned, Neeraj Ghaywan (Hindi), Subodh Nagdeve (Hindi), Nagraj Manjule (Marathi), Pa Ranjith (Tamil), Shavanas K. Bavakutty (Malayalam), Mari Selvaraj (Tamil) and Divya Bharathi (Tamil) could be mentioned. Among musicians, Punjabi folk, rap and hip-hop singer Ginni Mahi, and Hindi rapper Sumit Samos deserve special mention.
} 
capital that filmic techniques, production and distribution demand have prevented Dalits from playing a relevant role in this domain, and this in spite of the fact that they have always been part of the industry as labourers. Moreover, as was argued before, Dalits in films are often reduced to victim figures and, to make matters worse, these roles are almost always played by non-Dalit actors, such as Saif Ali Khan, Naseeruddin Shah and Shabana Azmi, to give but some well-known examples. This being said, it is also true that the advent of globalisation and new modern media and social platforms have contributed, not only to reinventing the very dynamics of cinema production and consumption, but also to developing new film genres that dare to question and counter hegemonic ideologies and aesthetics. This led, without doubt, to the emergence of an explicitly Dalit cinema, which Yengde describes as

an act of defiance leading to a sustained cinematic struggle. [...] a celluloid movement of visual creative art, made by Dalit film-makers, relating to Dalit subjectivities, inspiring socio-cultural criticism, [...] a universal monument of time and space. (2018: 1; emphasis in original)

The main aim of these film-makers will be, according to Edachira (2020: 1), to bring to the fore "the unconscious of caste" that had previously remained hidden and, which is even more important, to create new expressive means that can arouse affective responses among spectators. To put it differently, they will implement two different kinds of processes: one of denunciation of dominant casteist images, and one of innovation of ground-breaking anti-caste aesthetics that can alone affect the medium itself. These processes, Edachira goes on to argue, will accordingly prompt spectators to question conventional practices and, even more importantly, ponder the implications and ethical dimension, at once political and poetic, of the often unquestioned caste system. Bearing this in mind, it is my contention that anti-caste aesthetics should therefore become anti-caste aesthet(h)ics.

Asuran, a 2019 Tamil-language action drama film written and directed by Vetrimaaran and produced by Kalaipuli S. Thanu under his production banner V Creations, is a clear case in point. Based on Poomani's novel Vekkai, published in 1982 and translated into English thirty-seven years after its writing as Heat by N. Kalyan Raman, this film also goes beyond the mere portrait of a child murderer in order to explore the rather more complicated landscape that surrounds the murder. Violence is here depicted as culturally inherited, as the ultimate consequence of the unfair and degrading power dynamics prompted and perpetuated by casteism.

The film starts with a man in his mid-forties and a young boy wading across a river and carrying homemade bombs, sometime in the period of $1960 \mathrm{~s}$ to $1980 \mathrm{~s}$ in Tirunelveli (Tamil Nadu). Meanwhile, a woman, a man and a young girl are hiding from the police in a different part of the village. The voice of an external narrator soon informs in a flashback of all of their identities: the man is Sivasaami and the boy is his son Chidambaram; on the other hand, the woman, man and child are Sivasaami's wife Pachaiyamma, her brother Murugesan and daughter Lakshmi respectively. This narrator also says that this couple had an elder son, Velmurugan, with whom Sivasaami had a much closer relationship, and that they 
were, like most inhabitants of Thekkoor (meaning southern village), a family of Dalit farmers. Narasimhan was an upper-caste landlord from Vadakoor (meaning northern village) who desperately wanted Sivasaami's land to build a factory on it. The family, especially Velmurugan, were not at all interested in selling. One day Narasimhan's sons tried to dry up their well, Pachaiyamma did her best to stop them and was consequently attacked, and Velmurugan injured these men in response. He was arrested, and in order to get him released Sivasaami had to humiliate himself touching the feet of every male of the landlord's village. As soon as Velmurugan knew about this, he beat Narasimhan with a slipper when the latter was on his own in a public toilet. In revenge, Narasimhan's henchmen lynched and beheaded Velmurugan in the presence of his younger brother, who would take it upon himself to kill Narasimhan one year later to avenge his family. Sivasaami managed to cut the lights to help his son escape, told the family what had happened and fled with him. At this moment the film moves back to the present. Kariyan, Narasimham's most feral henchman, is told to lead a group of hunters to track them down.

When he is about to kill Chidambaram, Sivasaami steps in and bravely defeats all of them but kills none. It is when father and son are trying to recover that Sivasaami explains why he finally decided to spare their lives. Being only a youngster, Sivasaami recounts, he became the most famous and knowledgeable moonshine brewer, and thus one of the most appreciated servants of Viswanathan, a powerful landlord. Feeling sorry for Pandiyan, one of Viswanathan's distant relatives, Sivasaami convinced his master to employ him as an accountant. Meanwhile Murugan, Sivasaami's brother, and Seshadri, an upper-caste communist lawyer, were trying to reclaim for their Dalit community the land that the landlords had taken from them in the past. ${ }^{3}$ Sivasaami fell in love with Mariyamma and, when he gave her sandals as a token of love, Pandiyan felt offended and, displaying his injured caste pride, forced her to walk with them on her head in front of the whole village. On knowing this, Sivasaami retaliated by also hitting him with sandals and beating him and his men up, which infuriated Vishwanathan, who told him off in public. One night, before the meeting that was being organised by Murugan to address the other labourers was held, they were told that their lawyer had been arrested. Sivasaami went to get the papers authorising the meeting, and when he returned he found out, much to his desperation, that his brother and the other villagers had been killed by Pandiyan and his men, while Mariyamma and many others had

${ }^{3}$ Asuran denounces the usurpation of Dalit land that has taken place for so long in India. As Ilangovan Rajasekaran (2021) explains, the British government, with a view to improving the situation described by an 1891 report on the subhuman living conditions of Pariahs-Dalits nowadayssubmitted by James H.A. Tremenheere, at that time Acting Collector of Chengleput, passed the Depressed Class Land Act 1892, whereby 12 lakh acres of land were assigned for distribution to the 'depressed classes' of the Madras Presidency in an attempt to empower them socially and economically. However, to this day and as this film shows, much of this land is in the hands of non-Dalits, and the struggle to reclaim it has not been very successful. 
been being mercilessly burnt alive inside their huts. ${ }^{4}$ In revenge, Sivasaami killed Vishwanathan, Pandiyan and all their henchmen. Sivasaami then tells his son that he fled the village and ended up working as a farmer for Murugesan.

On hearing what he had done to avenge his family, Pachaiyamma, Murugesan's sister, fell in love with him. Sivasaami surrendered to the court, was given a light sentence on the grounds of self-defence, and soon afterwards married Pachaiyamma. After listening to this, Chidambaram radically changes his mind and starts understanding and admiring his father. After having a short encounter with his wife and daughter, Sivasaami visits Seshadri and asks him for help. The lawyer agrees to do so providing that he and his son turn up in court the following day. When they both enter the court premises, they realise Narasimhan's men are already there trying to ambush them, which forces them to flee. Sivasaami eventually agrees to sell his land to protect his family from Narasimhan's violence. In spite of this, the landlord's men violate the agreement and abduct and torture Chidambaram. Sivasaami cannot take this anymore and kills and injures many of Narasimhan's relatives and henchmen. Murugesan and the rest of villagers arrive armed and fight against Narasimhan's men. In the end, both villages decide that the conflict should cease in order to prevent a lethal caste clash. Sivasaami finally agrees to go to jail to protect all of his family, and Chidambaram in particular. The film ends with Sivasaami smiling at his family and telling his son to study hard so as to be able to stand up against oppression before he definitely enters the court.

Several are the strategies that Asuran uses to denounce casteism and promote anti-caste aesthet $(\mathrm{h})$ ics. To begin with, it is its genre unpredictability that makes the film different. Asuran is neither a heroic tale-Sivasaami is depicted in the first part of the film as a wimpy drunkard who has renounced his role of bonus pater familias - nor a revenge drama -unlike revenge dramas, which end with the killing of the enemy, this film ends up rejecting outright revenge and advocating instead the importance of education to overcome casteist obstacles and achieve freedom. It is, to quote Yogesh Maitreya's words in Firstpost, "the rebel biopic of an entire community, who from being called untouchables have recently shed their victimhood; who've adapted democratic means and asserted that with education a world with justice, fraternity and liberty is possible." Asuran plays with the unconscious feelings and expectations of the audience. If, as Wankhede affirms (2020), in mainstream Indian cinema "the possibility that the Dalit character [...] may enter to transform the terrible social structure by 'fist of fury' or by philanthropist grace is not an admissible topic," Asuran eventually bestows Sivasaami with outstanding skills, grace and humanity, in a word, with the credentials of the prototypical Bollywood hero who has the power to make changes. Actually, the second part of the film offers a drastically different

4 This arson fire no doubt brings to mind the notorious 1968 Kilvenmani massacre, in which forty-four Dalit agricultural labourers were locked inside a hut and burnt alive to teach their community a lesson, and which Dalit author Meena Kandasamy would denounce years later in her polemical novel The Gypsy Goddess (2014). 
portrait of Sivasaami, both as a loving husband and father and a brave and fearless warrior who is nonetheless reluctant to kill his adversaries. As a result, spectators find it difficult to classify the film generically and are thus forced to think outside the box and beyond their comfort zones.

Secondly, the film strives to transcend language barriers so as to reach a wider spectatorship through the use of subtitles in English and remakes (Asuran is currently being adapted in Telugu as Naarappa, starring Venkatesh and directed by Srikanth Addala), and a big circulation through large-scale national theatrical release -it was planned to be released in October 2019, coinciding with the occasion of Gandhi Jayanti and the weekend of the Vijayadashami festival in India- and the use of media platforms as Amazon Prime. Moreover, this film partakes of the interest that many Dalit film-makers show when highlighting the politics of naming: the choice of 'asuran' (meaning 'demon') is by no means accidental: contrary to what is expected from a Dalit man (submissiveness, impotence, marginality), Sivasaami is finally endowed with the strength and energy of a supernatural being capable of channelling them according to his own will. By attributing this label to a Dalit, a new dimension is given to this term, which stops having an exclusively negative meaning in order to encapsulate instead the superiority and resilience of a survivor who refuses to imitate the cruelty of those who want to destroy him.

The use of sound and music, and by contrast the irruption of deafening silence to emphasise the intensity of emotions and the loquacity of death, also deserve special mention. Silence embodies, to quote Edachira again (2020: 6), "the unnameable, [that] which cannot be brought into language as sound." Not in vain are some of the most heart-breaking scenes of the film devoid of any music. By contrast, those in which Sivasaami brings out the warrior in him are accompanied by a song whose lyrics once and again encourage him to rise, that is, to keep on fighting and resisting: "Rise! Against all odds. [...] Rise! To hunt them down, hunt them till they howl in pain, rise to agitate, to annihilate, make them tremble in fright"; "Rise Asuran! Rise Asuran!” (01:11:32-01:15:56; 01:46:07-01:48:32; 02:08:50-02:11:14) Paradoxically, some of these violent fight scenes are slow-motion ones, as if the camera's low speed were trying to further magnify Sivasaami's courage and determination. As regards the soundtrack album and background score, they significantly aim to interweave the local and the global, thus countering the assumption that Dalit productions are parochial and unable to appeal to an international audience. In an interview with The Times of India, the composer, G.V. Prakash Kumar, affirmed: "Asuran's music will be rooted, with raw folk being the dominant element, with earthy songs. But the approach is international. The thought process was about mixing folk and world music; the voices will be folk, but the instrumentation will have an international flavour, like using an electric guitar with this raw folk."

Symbols also play a significant role in the film. For example, the wild pig that enters Sivasaami's field becomes a subtle but crucial subtext as it brings to light the power relations between the characters. Both Sivasaami and his elder son try to capture it, but the pig finally manages to escape crossing into Narsimham's field, which is surrounded by an electrified fence. A very different fate awaits Sivasaami's dog: in its chase after the trespasser, it gets electrocuted and finally dies (00:17:05- 
00:19:56). As Maitreya suggests in Silverscreen India (2020), "the barbed wires stand as the symbol for untouchability, which a wild/stray animal can cross but not men from Dalit community nor their pets." Furthermore, the dichotomy pig vs. dog could be interpreted as signalling the clash between the immunity of unjust and brute forces and the vulnerability of decency and marginality. Velmurugan's missing head also denounces the extreme violence inflicted on Dalits. Narasimhan orders to cut his head off because he doesn't want his family to even find his body to cry over.

The Dalit body consequently signals the public realm subjected by violence. Although Sivasaami and his wife finally find Velmurugan's mutilated body, completely naked and eaten up by dogs, they cannot even file a complaint: till the head appears, this is an unidentified body, not their son's body. Not only has the landlord taken their son's life, but he has also deprived him of his identity, his dignity, and his family of their right to wake him properly; Velmurugan has been reduced to the sheer physicality of an abject body. Slippers can also be seen as a symbol of all the privileges that the upper castes enjoy and refuse to share with the lowest; when a Dalit person dares to claim the same rights in the name of the democracy the country so often flaunts, s/ he not only has to face scorn and humiliation but also has to pay too high a price, namely, to lose what is most precious to her/him, the ones s/he loves. On the other hand, slippers can also be seen as encapsulating the power of the wretched of the earth, to rely on Frantz Fanon's well-known expression, to defy the structures that oppress and degrade them. And the same could be said of the home-made bombs that Chidambaram so carefully carries with him: however destitute they may be, Dalits still have the power to undermine the system that crushes them from within. Colours also contribute to highlighting contrasts: whereas upper-caste men often wear white, which clearly points to their privilege status, Sivasaami's turban is blue, popularly considered the colour of Dalit liberation (Edachira 2020: 11). Last but not least, the final close-up of Sivasaami's smile symbolises the ultimate acquisition of moral authority and meaning in the life of this warrior, who has dared to defy casteism and firmly demand a dignified life for him and his peers.

In addition to reconceptualising the notion of the hero, women characters are also depicted beyond well-known cinematographic stereotypes. In mainstream Indian cinema, subaltern female characters often fall prey to humiliation. In contrast, the double face of archetypal female characters only seems to describe some uppercaste women. According to Yengde (2018: 12), this archetypal woman figure is "frequently presented as loyal, fasting for the welfare of her husband, but she is also overtly dramatic, deceitful, conceited, a scaremonger and a cheat who is very competitive with other female characters." This is a prototype that has very little to do with the reality of most Dalit women, nor with their representation in Dalit films, which often resists both victimhood and glamour.

Contrary to the archetypes described before, in Dalit cinema Dalit women are shown as forthcoming, assertive, full of energy and agency, capable of defying the system and fighting for their rights with self-respect and dignity. The heroines in Neeraj Ghaywan's Masaan (2015, Hindi) and Shavanas K. Bavakutty's Kismath (2016, Malayalam) could be given as examples. This is also, no doubt, the case of Mariyamma, who dares to defy her family to marry Sivasaami (they preferred 
a farmer to a brewer) and proudly wears the sandals he gave her on her way to school, and of Pachaiyamma, who chooses Sivasaami as a husband on account of his courage, faces up to the landlord's men when they want to deprive her family of water (00:23:40-00:24:36), and unconditionally sides with her husband when things go wrong and he must flee with Chidambaram, fending for herself and their young daughter with the help of her brother.

In keeping with Edachira's contention (2020: 2) when describing the innovative character of contemporary Dalit films, it could also be asserted that Asuran strives to demonstrate that caste is strongly embedded in the sensorial regime, and that sensorial regimes are in turn closely linked to aesthetics. Dalits are the former untouchables and have consequently become a 'touchy' subject for Indian cinema, one that, as Edachira goes on to argue, "either it resolves itself within a Gandhian (religious/cultural) or a Nehruvian (statist) paradigm but never ethico-politically" (2020: 6). If 'touch' means 'to bring a bodily part into contact with, especially so as to perceive through the sense of feeling,' it can also suggest 'to concern oneself with' (Longman Webster English College Dictionary). Furthermore, it is a fact that, without any actual physicality involved, films can 'touch' their audiences and arouse all sorts of feelings in them. As regards Dalit films like the one under analysis, their innovative subversion lies, above all, in their interest to touch spectators and reach out to the other through the use of affective anti-caste aesthetics. To put it differently, they strive to emphasise Dalits' humanity, that is, to express the unnameable, to turn into a presence what had so far been an absent entity to the audience's sensory reality. Although some minor differences can be noticed among Dalit films, mainly on account of the Indian states in which they were made and their respective cultures and speaking languages (above all Hindi, Marathi, Tamil and Malayalam), it could be argued that, on the whole, they all deal with the same important issues.

Unlike other popular films that exclusively focus on the negative aspects of Dalits' marginal life and humiliation, Asuran takes pains to also showcase their struggles, love relationships and affection for one another. It is solidarity that brings Dalits together: when Sivasaami apologises for causing their relatives trouble by asking them to hide his wife and daughter while he and his son run away, the one he addresses merely replies "No needs for thanks between us." Moreover, given the fact that Dalits are not only untouchables, but also unhearables and unseeables, the use of affective anti-caste aesthetics allows the film to make them touchable, audible and visible, in a word, human, which significantly questions the sensorial regime of caste. However, it must also be noticed that, although cinema is an audiovisual medium and, as was argued before, sound and music play a very important role in films, it is the sense of sight, and particularly the gaze, that is often privileged over the rest of senses. Hence the importance of on-screen visual elements, such as lighting, framing, composition and camera motion and angles, and even the occasional inclusion of visual items belonging to a different ontological level.

Accordingly, Dalit films like Asuran aim to cultivate what Edachira (2020:3) labels as "an oppositional gaze as well as a 'look' which cares." To start with, the film at one point dares to call the spectators' attention towards the sheer artificiality of the medium: the voice over narrator explains that Sivasaami's landowner wants to 
build a cement factory on the former's land by juxtaposing drawings and sketches of the project with real images of the village (00:12:05-00:13:18). Reality and virtual reality conflate. Lighting often echoes their terrible situation, as dark scenarios are omnipresent in the film. Framing also seems to take sides with Dalits. To give but one example, when Sivasaami is made to confront his landlord at the Council meeting, the latter's hazy face is on the left, whereas Sivasaami's sharp image occupies the right part of the frame. Similarly, the policeman who refuses to let them file a complaint when his son Murugan disappears is sitting on a chair on the left hand side of the screen while Sivasaami stands up on the right. Whereas right and left clearly seem to mean right and wrong, the fact that it is Sivasaami who is on his feet clearly highlights his pride and decency, in opposition to the corrupted policeman's comfortable submission to those holding power.

Although the use of high angle shots often contributes to depicting them as helpless tiny specks at the mercy of forces they cannot possibly control, as when father and son flee the village to escape the landlord's men's revenge, it is also true that the film contains a significant number of scenes in which the members of this Dalit family take up the whole screen while openly showing affection towards one another. To mention but some, a close up of Sivasaami's face reveals his suffering when his son Murugan returns home badly beaten up by the landlord's men (00:32:0000:32:12); another shows him crying as he remembers his wife and exclaims, "Where have you gone, sweetheart?” (01:06:01-01:06:34); another highlights Pachaiyamma crying over her missing elder son (00:46:11-00:46:13); a long medium shot shows Sivasaami and his wife lovingly embracing Murugan's beheaded body (00:39:6000:42:15), and later on another similar shot showcases Pachaiyamma caressing her younger son as he lies down on her lap (00:47:25-00:47:54).

Special attention deserves as well the section of the film in which, in consonance with the widely celebrated Bollywood love scenes, Sivasaami and Maariyamma happily dance in the rain surrounded by lots of smiling children while the camera follows all their movements to always keep them centre stage and, last but not least, the shot/reverse shots Sivasaami/ Pachaiyamma/ Sivasaami/ Chidambaram/ Sivasaami which, together with Sivasaami's advice to his son at the very end of the film, endow the former with the prominence and moral authority of an unquestionable hero (02:15:28-02:15:58). The verb 'rise' is again mentioned by Sivasaami, but this time to prevent Chidambaram from living in hatred: "if we have education they can never take it away from us. If you really want to win against them, study [...] and become a powerful man. But when you have the power, don't do to anyone what they did to us. It's easy to deepen hate but we must rise above it." It is in Sivasaami's final message that lies his superiority. Revenge is never the answer, but salvation lies exclusively in their hands, in their capacity to overturn the injustices concomitant with the caste system through education. 


\section{CONCLUSION}

Unlike mainstream Indian cinema, whose main aim has always been to perpetuate and celebrate the status quo, Dalit films strive to question and deconstruct it. It is undeniable that caste inequality can only be undermined with a common Dalit discourse of resistance. The emergence of anti-caste movements in the 1960s and 1970s, together with the subsequent growth of Dalit literature, greatly contributed to strengthening the links between these oppressed communities. Yet, since the political very often overpowered the literary aesthetics, Dalit literature mainly remained for several decades as an alternative, rather than an opposition, to mainstream literature. As the analysis of Asuran has shown, when it comes to discussing Dalit cinema, the ever-increasing use of anti-caste aesthetics has not only questioned mainstream cinema, but has also affected the medium itself through the implementation of an affective expressive aesthetics that is at once political and poetic, and in turn mainly concerned with bringing to the fore all sorts of ethical issues. Hence my use of the term aesthet(h)ics.

By challenging upper-caste prejudices and the different forms of oppression that these inevitably bring about, Dalit films like Asuran have departed from traditional forms of art in order to launch an unprecedented campaign against hegemonic caste privileges. Not only have they incorporated formerly unrecognised identities into their subject matter, but they have also introduced and encouraged a new aesthetic paradigm, which can by no means be detached from its militant questioning of pale skin, caste supremacy and the biased pronouncements by Indian elites. This, together with the fact that modern media has reinvented the mechanisms of film-making by developing new genres that have challenged traditional film-making norms, has strengthened the cinematic presence of Dalits in the Indian film industry.

It is also true that there is still a long way to go before it can be affirmed that Dalit-directed films are prominent in the Indian filmic scene. Indian film criticism has widely proved its elitism by systematically turning a blind eye on the social restraints and injustices of casteism and Indian society in general. To rely on Walter Benjamin's words (2008: 329) by means of conclusion, given the fact that the politics of sanctioned denial have become "the political position" of Indian cinema, the only way in which this phenomenon can be countered is by making sure that "the political position being transformed -as if on its own- from a deeply hidden element of art into a manifest one." Dalit cinema's ultimate target should be to aspire to become a new kind of socially conscious cinema that somehow straddles commercial and art cinemas, and by extension partakes of an empowering new mainstream filmic culture. Resistance and engagement have always been the prerogative of committed art, whose potential and possibilities are consequently unlimited. As artistic and ethical constructs, Dalit films have not only the ability to bring to the fore Dalit oppression, but they can also contribute to changing the rigid Indian social fabric by openly denouncing and undermining long-time enforced caste dogmas and aesthetics.

Review sent to author: 28/05/2021

Revised version accepted for publication: 04/07/2021 


\section{WORKS CITED}

Benjamin, Walter. The Work of Art in the Age of Its Technological Reproducibility, and Other Writings on Media. Eds. Michael William Jennings, Brigid Doherty \& Thomas Y. Levin. Transl. E.F.N. Jephcott, Rodney Livingstone \& Howard Eiland. Harvard University Press, 2008.

Butalia, Urvashi. “Women in Indian Cinema." Feminist Review 17 (1984): 108-110.

Chadha, Kalyani and Anandam Kavoori. "Exoticised, Marginalised, Demonised: The Muslim 'Other' in Indian Cinema." In Global Bollywood. Eds. Kavoori, Anandam \& Aswin Punathambekar. New York University Press, 2008. 131-145.

Edachira, Manju. "Anti-Caste Aesthetics and Dalit Interventions in Indian Cinema." Economic and Political Weekly 55/38 (19 Sept 2020): 1-15. https://www.proquest.com/docview/244 4848435?accountid=14778. (Last accessed 23 September 2020).

Maitreya, Yogesh. "Indian Cinema and the Dalit Identity: In Dhanush's 2019 Film Asuran, the Rise of a New National Hero.” Firstpost (4 Sept 2020). https://www.firstpost.com/art-andculture/indian-cinema-and-the-dalit-identity-in-dhanushs-2019-film-asuran-the-rise-of-anew-national-hero-8783631.html. (Last accessed 6 March 2021).

Maitreya, Yogesh. "Asuran: A Detailed Analysis of the Symbolism in Crucial Scenes and Why It Represents How Dalits Live in India." Silverscreen India (7 Sept 2020). https:// silverscreenindia.com/movies/features/asuran-a-detailed-analysis-of-the-symbolism-incrucial-scenes-and-why-it-represents-how-dalits-live-in-india. (Last accessed 6 March 2020).

PAL, Ayantika. "Why are Dalits Missing from Indian Cinema and Media?" India Resists (5 April 2019). https://www.indiaresists.com/why-are-dalits-missing-from-indian-cinema-andmedial. (Last accessed 2 April 2021).

Rajasekaran, Ilangovan. “How Dalit Lands Were Stolen.” Justice News (21 April 2021). https:// www.justicenews.co.in/how-Dalit-lands-were-stolen. (Last accessed 23 April 2021).

The Times of India. "I've treated Asuran like a Coke Studio project: G.V. Prakash." nd http://www. speakchennai.com/index.php/ive-treated-asuran-like-a-coke-studio-project-gv-prakash. html. (Last accessed 6 March 2021).

Vidushi. "Cinematic Narrative: The Construction of Dalit Identity in Bollywood." In Media, Margins and Popular Culture. Eds. Einar Thorsen, Heather Savigny, Jenny Alexander \& Daniel Jackson. Palgrave MacMillan, 2015. 123-135.

Wankhede, Harish S. "It's 2020, and We Still Don't Have an Iconic Dalit Hero in Bollywood." Huffpost (6 Sept 2020). https://www.huffpost.com/archive/in/entry/dalit-hero-bollywoodhindi-cinema_in_5f54532ec5b6578026cf14cd. (Last accessed 2 April 2021).

Yengde, Suraj. "Dalit Cinema." South Asia: Journal of South Asian Studies 41/3 (2018): 1-16. https:// doi.org/10.1080/00856401.2018.1471848. (Last accessed 23 September 2020). 
